\title{
ARTYKUtY
}

Klio. Czasopismo poświęcone dziejom Polski i powszechnym

PL ISSN 1643-8191, t. 53 (2)/2020, s. 67-81

(c) $\odot$

http://dx.doi.org/10.12775/KLIO.2020.019

\author{
Pawee Duma
}

\section{Magia ochronna przeciw czarounicom, złemu urokowi oraz inne środki apotropaiczne w śuietle znalezisk archeologicznych w Europie}

\author{
Protective magic against witchcraft, evil spell, \\ and other apotropaic means in the light \\ of archaeological excavations from Europe
}

Streszczenie: Prezentowany artykuł omawia znaleziska archeologiczne pochodzące z Europy, które interpretuje się jako depozyty mające chronić przed szkodliwym działaniem czarownic lub innych osób i mocy. Autor omawia kolejno kwestię ofiar zakładzinowych i znalezisk zblizzonego rodzaju. Znalazły się w nim przedmioty wykonane $\mathrm{z}$ ołowiu, na których umieszczono inskrypcje mieszane składające się z zaklęć i modlitw, a także znaków magicznych. Zwyczaj ten w okresie średniowiecznym był rozpowszechniony w Skandynawii i w rejonie północnych Niemiec. Jego korzenie sięgają starożytności. W miejscowości Kyritz w Brandenburgii odnaleziono naczynie, w którego wnętrzu złożone zostały taśmy

Instytut Archeologii Uniwersytetu Wrocławskiego, ul. Szewska 48, 50-139 Wrocław, pawel.duma@uwr.edu.pl, ORCID: 0000-0001-7991-3133. 
ołowiane z podobnymi inskrypcjami. Odkrycia tego typu przedmiotu z XII w. dokonano również przy grodzisku Dřevíče w Czechach w 2014 r. Natomiast w Stralsundzie odkopano figurkę antropomorficzną z wyrytymi na powierzchni znakami i zaklęciami. Autor omawia również zabytki znajdujące się w budynkach, m.in. kartki zapisane zaklęciami ochronnymi ukrywane w wywierconych w belkach otworach. Wiele takich znalezisk jest znanych z terenów Niemiec, ale też Francji, Luksemburga czy USA. Kolejna część została poświęcona zjawisku zakopywania tzw. butli czarownic - naczyń zawierających przedmioty żelazne, włosy, paznokcie i ludzką urynę. Ukrywano je z intencją uleczenia choroby i ukarania winnej jej powstania osoby - w tym przypadku wierzono, że była nią czarownica. Liczne butle z taką zawartością pochodzą z terenów Anglii. Kilka odnaleziono również w USA. W ostatniej części znalazły się informacje dotyczące chowania łożysk poporodowych w naczyniach. Naczynia z taką zawartością ukrywano w piwnicach budynków lub pod podłogami pomieszczeń gospodarczych. Niektóre z naczyń miały wymalowane znaki ochronne lub inicjały matek. Wiele z nich odkopano w Niemczech. W ostatnim czasie odkryto je także w Polsce. W Lubaniu natrafiono łącznie na ok. 100 naczyń w 20 różnie lokalizowanych piwnicach budynków. Uważa się, że pierwotnie także w nich deponowano łożyska. Artykuł skupia się na znaleziskach, których związek z dawnymi wierzeniami magicznymi rysuje się wyraźnie.

\begin{abstract}
The paper discusses archaeological excavations from Europe interpreted as deposits against witchcraft, witches or other persons with some sort of power. Author investigates an offering custom and a variety of objects connected with the phenomena, i.e. lead object with magical spells, prayers, and magical signs. The custom was widespread in medieval Scandinavia and Northern Germany, however it originates from Ancient times. Author presents excavations and minor objects discovered inside buildings, i.e. pieces of paper with written spells hidden in wooden beams. Many discoveries of this kind come from Germany, however similar written spells are known from France, Luxembourg, or the United States of America. The paper discuss other issues as well. Author presents "witches' bottles", or vessels filled with irons subjects, hair, nails, and urine. These vessels were hidden to cure any illness and to punish a person responsible for this illness it was believed that the person was a witch. Numerous "bottles" of this kind have been discovered in England, some of them are known from the USA. The author discusses also a custom of putting pieces of placenta into the vessels discovered inside buildings, in cellars or under a floor. Numerous discoveries with this kind are known from Germany and recently from Poland as well.
\end{abstract}

Słowa kluczowe: magia, czarownice, apotropaizm, archeologia

Kedywords: magic, witches, apotropaism, archeology 
agadnienia związane $\mathrm{z}$ magią i stosowanymi w przeszłości środkami
apotropaicznymi od lat rozpalają wyobraźnię badaczy. Atmosfera narosła wokół odkryć łączących się z omawianym tematem przyczyniła się do ich rozpropagowania i lepszego poznania, lecz również do utrwalenia niepotwierdzonych sądów i interpretacji, które po głębszej analizie okazują się słabo uzasadnione. W tym artykule skupimy się jedynie na prezentacji przykładów tych znalezisk, których związek ze strachem przed niepożądanymi siłami czy działaniami osób „szkodliwych” wydaje się jasny. Z przyczyn oczywistych nie będziemy analizować zjawiska w całej rozciągłości i rozbudowanej dyskusji toczącej się na jego temat, o ile nie będzie to potrzebne do naświetlenia przedstawianych materiałów. Pośród licznych poglądów prezentowanych w literaturze można natrafić na stwierdzenie, że magia, zwłaszcza ludowa, jest prymitywniejszą formą religijności ${ }^{1}$. Obecnie uważa się, że zagadnienia dotyczące magii i religii nie mogą być rozpatrywane rozdzielnie, a granica między nimi jest w istocie labilna.

Działania magiczne, które miano wykonywać w przeszłości, w wielu przypadkach nie pozostawiają śladów uchwytnych archeologicznie. O samym ich bogactwie informują nas przekazy etnograficzne lub historyczne. Istnieje jednak grupa zabytków ruchomych, pojawiających się w kontekście badań archeologicznych, które udowadniają stosowanie przynajmniej wybranych środków apotropaicznych w przeszłości.

Wiele niejasności jest spowodowanych brakiem prostej definicji prezentowanego zagadnienia. Do najobszerniejszych opracowań odnoszących się do interesującego nas tematu nadal zalicza się praca opublikowana przez Ralpha Merrifielda² w 1987 r. Autor prezentuje w niej znaleziska o charakterze magicznym - od okresu pradziejowego po czasy współczesne, dokonując szczegółowego ich przeglądu i zmieniając utarte schematy interpretacyjne. Przed wspomnianą publikacją nie było podobnej syntezy. Od daty jej wydania ukazało się jeszcze kilka prac, o których wypada wspomnieć.

${ }^{1}$ M. C. Manning, Magic, religion, and ritual in historical archaeology, w: Manifestation of magic: the archaeology and material culture of folk religion, eds. C. C. Fennell, M. C. Manning, „Historical Archaeology” 2014, vol. 48 (3), s. 1-9, tu: s. 1.

2 R. Merrifield, The archaeology of ritual and magic, Batsford 1987. 
Są to głównie tomy pokonferencyjne ${ }^{3}$, zawierające artykuły mniej lub bardziej związane z interesującym nas zagadnieniem. Ukazują jednak, że stan wiedzy na opisywany temat uległ poszerzeniu od czasów publikacji pracy Merrifielda. Przybyło również nowych znalezisk. Wybrane z nich zreferujemy poniżej.

Wśród wielu przywoływanych zabytków w kontekście magii ochronnej wymienia się ofiary zakładzinowe - najczęściej naczynia - które w ogólnym rozumieniu, składane pod węgłem domu, miały strzec domowników i zapewnić szczęście inwestycji. Zalicza się do nich również kości zwierzęce, najczęściej czaszki, i drobne przedmioty, jak np. figurki ${ }^{4}$. W wielu przypadkach naczynia odkrywane w podobnych kontekstach nie były analizowane specjalistycznie pod kątem zawartości, a kości zwierzęce występujące powszechnie w nawarstwieniach kulturowych trudno jest nieraz pewnie powiązać z pozostałościami odkrywanych budowli. Zdarza się, że podobne nagromadzenia szczątków odnalezione blisko reliktów domostwa określa się mianem ofiar zakładzinowych, podczas gdy takie skupiska kości, zalegające w sąsiedztwie, są uznawane za odpady pokonsumpcyjne. Należy pamiętać o tym, że kości mogły się dostać do ziemi przed datą wystawienia budynku lub intencja osoby je zakopującej była zgoła inna. Niewątpliwie podobne zwyczaje były praktykowane, ale mało jest ewidentnych przykładów je potwierdzających. Warto również mieć na uwadze, że ofiar tych nie zakopywano jedynie w ziemi, ale również umieszczano $w$ innych miejscach. Są one odkrywane w ścianach istniejących budowli historycznych, elementach konstrukcyjnych czy innych trudno dostępnych miejscach. $\mathrm{Z}$ tego

3 „Verflixt!“- Geister, Hexen und Dämonen, Hrsg. J. Carstensen, G. Apel, Münster-New York-München-Berlin 2013; „Damit's Kind g'sund bleibt“ - Tabu Nachgeburtsbestattung - Kolloquiumsbericht, Hrsg. K. Sartorius, Bönnigheim 2004; Religion, cults \& \& rituals in the medieval rural environment, eds. C. Bis-Worch, C. Theune, „Ruralia”, vol. 11, Leiden 2017; Manifestation of magic...

4 Pośród licznych publikacji traktujących o ofiarach zakładzinowych zwraca uwagę: K. Klusemann, Das Bauopfer. Eine ethnographisch-prähistorisch-linguistische Studie, Graz-Hamburg 1919. Autor zebrał i przedstawił wiele znalezisk naczyń i przedmiotów, które łączy z opisywanym zjawiskiem. Wiele z nich ma jednak słabo udokumentowany kontekst odnalezienia, mimo to praca nadal jest przydatna i dotyczy po części znalezisk pochodzących z Czech czy Śląska. 
powodu nie zawsze jest jasne, czy dany przedmiot został ukryty intencjonalnie, czy dostał się tam przypadkowo. Zwłaszcza jeśli chodzi o mumie zwierzą - najczęściej kotów i ptaków, a także obuwie oraz wiele innych przedmiotów5 5

Oprócz tego rodzaju znalezisk, o których jedynie wspominamy, jest jeszcze inna grupa, bez wątpienia mająca charakter apotropaiczny. Do tej grupy zalicza się m.in. odkrycie, którego dokonano w 2008 r. w miejscowości Kyritz ${ }^{6}$ w Brandenburgii. Na wschód od dawnych murów miejskich natrafiono tam na kamienne fundamenty budynku, który według odkrywców pełnił funkcje łaziebne. Potwierdziły to również liczne zabytki ruchome, takie jak: pincety, igły, grzebienie czy bańki gliniane. Odnaleziono również pozostałości studni średniowiecznej, używanej przynajmniej do połowy XV w. Na zachód od niej, w odległości 1,6 m, znajdowało się niewielkie zagłębienie o wym. $25 \times 30 \mathrm{~cm}$. W nim spoczywało naczynie stalowoszare, w którego wnętrzu umieszczona była poskładana taśma ołowiana. Dwa kolejne fragmenty taśmy, ułożone na krzyż, leżały w połowie jego wysokości. Depozytu miano dokonać w XV w. O przeznaczeniu całości świadczyła treść inskrypcji odnaleziona na taśmach. Wyryto na nich m.in. słowa i symbole o znaczeniu apotropaicznym (krzyże, okręgi, litery) (ryc. 1). Podobnego rodzaju znaleziska odnotowuje się głównie na terenach Skandynawii. Odnajdywane są tam one zarówno w grobach, jak i na osadach. Datuje się je głównie na XIII-XV w. Inskrypcje na nich notowane są wykonane runami, jak i za pomocą alfabetu łacińskiego ${ }^{7}$. Treść inskrypcji ma zazwyczaj charakter mieszany. Są to zaklęcia magiczne oraz fragmenty modlitw. Podobne taśmy ołowiane z inskrypcjami na terenie Niemiec zostały znalezione w Szlezwiku, w nawarstwieniach średniowiecznych oraz w grobach

5 K. Freckmann, Bauopfer und ähnliche magische Praktiken, w: „Verflixt!“..., s. 75-84; J. Costello, Tracing the footsteps of ritual: concealed footwear in America, w: Manifestation of magic..., s. 35-51.

${ }^{6} \mathrm{~J}$. Anders, Schröpfgefäß und Beschwörungsformeln. Ein Badehaus in der Altstadt von Kyritz, Lkr. Ostprignitz-Ruppin, „Archäologie in Berlin und Brandenburg” 2008, s. $100-103$.

7 S. O. Rikke, Runic amulets from medieval Denmark, „Futhark: International Journal of Runic Studies" 2010, vol. 1, s. 161-176. 


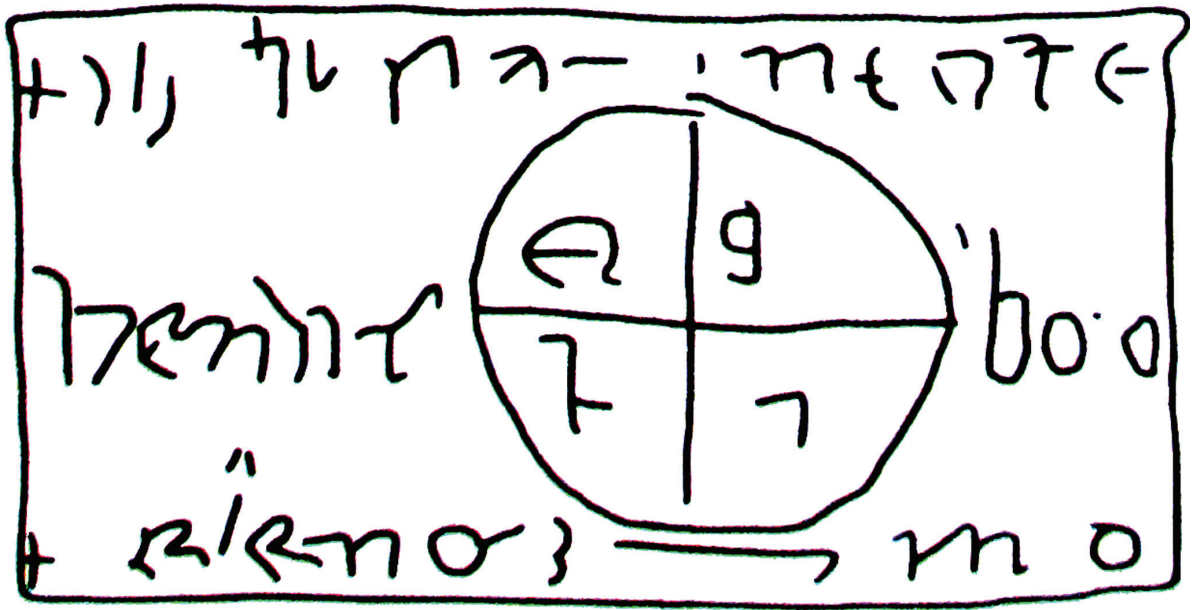

Ryc. 1. Przerys jednej z inskrypcji znajdującej się na taśmie ołowianej ukrytej w naczyniu wykopanym w Kyritz (Brandenburgia, Niemcy). Źródło: J. Anders, Schröpfgefäß und Beschwörungsformeln. Ein Badehaus in der Altstadt von Kyritz, Lkr. Ostprignitz-Ruppin, „Archäologie in Berlin und Brandenburg” 2008

dziecięcych w Halberstadt i Wolmirstedt (obie miejscowości w Saksonii-Anhalt) ${ }^{8}$. Na taśmach z Kyritz odczytano fragmenty inskrypcji, które interpretuje się jako najczęściej rozpowszechniony akronim kabalistyczny AGLA (Ateh Gibor Le-olam Adonai; „Ty, o Panie, jesteś potężny na wieki”). Skrót ten znalazł się również na przedmiotach odkrytych w grobie zlokalizowanym w Romdrup czy na osadzie w Blæsinge w Danii?

Jak się jednak okazało, występowanie podobnego rodzaju amuletów nie ogranicza się tylko do terenów północnych Niemiec czy Skandynawii. Możliwe, że zwyczaj ich stosowania był szerszy, niż zwykło się sądzić. Tabliczki ołowiane zawierające ochronne inskrypcje są znane już od starożytności. Odnajdywano je pod budowlami rzymskimi czy w trakcie badań wykopaliskowych prowadzonych na dawnych osadach ${ }^{10}$. Często po

8 J. Anders, op. cit., s. 102.

9 Ibidem, s. 103.

10 Por. np. omówienie jednego ze znalezisk z Wysp Brytyjskich: R. S. O. Tomlin, “Sede in tuo loco": a fourth-century uterine phylactery in Latin from Roman Britain, „Zeitschrift für Papyrologie und Epigraphik" 1997, Bd. 115, s. 291-294. 
wypisaniu inskrypcji ołowiane taśmy czy tabliczki były składane. Przypuszczalnie miało to spotęgować ochronną moc zaklęcia i ustrzec je przed niepożądanym wzrokiem. Taką złożoną tabliczkę z inskrypcjami o wym. $3,4 \times 4,3 \mathrm{~cm}$ odnaleziono $\mathrm{w}$ pobliżu grodziska Dřevíče w Czechach w 2014 r. ${ }^{11} \mathrm{~W}$ toku analizy przedmiot nie został rozłożony, stąd odczytano treść tylko na widocznych powierzchniach. Najdłuższy jego fragment brzmiat: „[...] dei contra fraud(em)/callidi diaboli [...]” („Bóg przeciw złośliwym machinacjom diabła”). Podobnego rodzaju przedmioty, często określane mianem amuletów, miały chronić swoich właścicieli przed działaniem złych mocy i chorobami. Wykonywano je również z pergaminu. Czas powstania czeskiego znaleziska, przez analogie i analizę paleograficzną treści, został określony na początek XII w. Ołów, jako metal miękki i łatwy w obróbce, występował najczęściej w formie przedmiotów, które wytwarzano z podobnym przeznaczeniem. Bez większego trudu można było na nim ryć inskrypcje lub znaki ochronne. Oprócz wspomnianych płytek znane są inne znaleziska wykonane z tego metalu, które opatrywano zbliżonymi lub identycznymi napisami. W Stralsundzie znaleziono figurkę ołowianą, na której wyryte zostały liczne znaki i słowa o charakterze apotropaicznym ${ }^{12}$. Odkrycia dokonano w trakcie prac prowadzonych na dawnej ul. Ossenreyerstrasse. Figurka została odnaleziona w piwnicy kamienicy stojącej pod nr. 57. Jej wnętrze zasypano jeszcze ok. 1800 r. Figurka została zakopana pod nieutwardzoną podłogą piwnicy, przy tylnej ścianie piwnicy i przykryta kamieniem. Jej wysokość wynosiła $12 \mathrm{~cm}$. Jest to prymitywne przedstawienie postaci ludzkiej odlane z ołowiu. Oddzielnie wymodelowano kontur oczu i ust. Autor badań sądzi, że figurka mogła zostać zakopana w celu ochrony domu, ale nie wyklucza działania skierowanego wobec konkretnej osoby (ochronnej lub szkodliwej magii). Datę powstania figurki, na podstawie stylu umieszczonego na niej pisma minuskułowego, określono na schyłek średniowiecza ${ }^{13}$.

11 K. Blažková et al., Stredověký olověný amulet z hradiště Dřevič (k. ú. Kozojedy, o. Rakovnik), „Archeologické rozhledy” 2017, Roč. 69, s. 121-142.

12 J. Ansorge, Kurze Fundberichte Mittelalter/Neuzeit, Hansestadt Stralsund, Fpl. 320, „Bodendenkmalpflege in Mecklenburg-Vorpommern” 2010 (2011), Bd. 58, s. 444-454.

13 Ibidem, s. 454. 
Tradycja umieszczania podobnego rodzaju przedmiotów o charakterze ochronnym utrzymała się właściwie do współczesności. Sposoby ich deponowania i rodzaje używanych materiałów były niezwykle szerokie. Różnorodność ta powoduje, że nie we wszystkich przypadkach można je poprawnie identyfikować. Wyraźnie widać to zjawisko w przypadku znalezisk dokonywanych podczas renowacji czy poszukiwań w starych budynkach. W ostatnich latach intensyfikacji uległy badania podobnego rodzaju, w efekcie których odkryto liczne depozyty zlokalizowane w różnych miejscach historycznych budowli ${ }^{14}$. Można się spodziewać, że znalezisk tych mogłoby być znacznie więcej, ale tylko w nielicznych przypadkach $\mathrm{w}$ trakcie prac renowacyjnych $\mathrm{w}$ roli obserwatorów uczestniczą profesjonalni badacze. Znajdowane depozyty umieszczano np. w uprzednio wywierconych dziurach w belkach konstrukcyjnych. Po włożeniu zawartości dziury powtórnie czopowano ${ }^{15}$. Wiele $\mathrm{z}$ takich odkryć dokonano w budynkach szkieletowych badanych w południowo-zachodnich Niemczech. Zazwyczaj otwory znajdowały się na niewielkich wysokościach (od 1 do $1,5 \mathrm{~m}$ ). Zawierały pozostałości roślinne, fragmenty skór i tkanin, skorupki jajek oraz - co najciekawsze - skrawki papieru zadrukowanego lub zapisanego odręcznym pismem. Zazwyczaj są to fragmenty stron wyrwane ze śpiewników lub zawierające fragmenty modlitw czy też Ewangelii. W przypadku odręcznie zapisanych treści są to zaklęcia, znaki oraz symbole o charakterze magicznym. Jeden z takich rozbudowanych listów został odnaleziony w budynku znajdującym się w Borg koło Osnabrücka. Uważa się, że powstał on w XVI lub XVII w. i zapełniono go zaklęciami mającymi chronić dom, inwentarz żywy, zbiory oraz produkty rolne przed działaniem czarownic ${ }^{16}$. Podobne odkrycia rejestrowano już w okresie przedwojennym. W miejscowości Trebel w Dolnej Saksonii w 1935 r., podczas przebudowy

14 Por. np. I. Nießen, Building sacrifices and magical protection. A study in canton of Grisons (CH), w: Religion, cults \& rituals..., s. 325-336; W. R. Wheeler, Magical dwelling. Apotropaic building practices in the New World. Dutch Cultural Hearth, w: ibidem, s. 373-396.

15 H. Stiewe, Magische Zeichen und Zauberbohrungen an Bauernhäusern in Nordwestdeutschland, w: „Verflixt!“..., s. 59-74; idem, Zauberbohrungen, magische Zeichen und „Hexenbriefe“, w: Religion, cults \& rituals..., s. 357-371.

16 Idem, Magische Zeichen..., s. 68. 
domu z 1691 r., odnaleziono wiele skrawków papieru z zaklęciami i znakami przeciw czarownicom. Fragmenty te, ukryte w różnych miejscach, były dokładnie poskładane i pozwijane. Umieszczono je w końcówkach odciętych piór gęsich i wypełniono piaskiem. Następnie lakowano. Ich wymiary były niewielkie i wynosiły nie więcej niż $4 \times 1 \mathrm{~cm}$. Na papierze znalazły się przedstawienia pentagramu ze skróconym tekstem wypisanym $\mathrm{w}$ środku: AdoNai AglA (z hebrajskiego: Adonai attah gibbor l'olano Adonai - „Panie, jesteś potężny na wieczność, Panie”). Ukrycia tych depozytów miano dokonać ok. 1800 r. Do tej pory zbliżone znaleziska są znane z Nadrenii, Hesji, Dolnej Saksonii oraz Szwajcarii. Jak jednak podejrzewają badacze, zwyczaj był rozpowszechniony w całej Europie Środkowej. W niektórych budynkach zadokumentowano kilkanaście podobnego rodzaju nawierceń zawierających zbliżone do opisanego wypełnienie. Jak zostało wspomniane, umieszczano je tam zazwyczaj przeciw czarownicom, ale również chorobom zwierząt i ludzi. Stosunkowo niedawno podobnych odkryć dokonano we Francji ${ }^{17}$. Z budynku w Narbéfontaine (Mozela, Francja) pochodzi ukryta w końcu XVII w. kartka papieru, na której znalazły się modlitwy i zaklęcia przeciwko złym mocom, spisane w języku niemieckim ${ }^{18}$. Z Anglii i Walii do lat 80 . XX w. zanotowano ok. 20 podobnych przykładów ${ }^{19}$. Co ciekawe, zwyczaj ten zawędrował również do Nowego Świata. Znane są znaleziska kartek zapisanych zaklęciami ochronnymi np. z rejonu Pensylwanii w Stanach Zjednoczonych. Na terenie zdominowanym w przeszłości przez osadników niemieckich kartki takie odnajdywano w stodołach. Miały chronić inwentarz żywy. Prócz zaklęć rysowano na nich również symbole astrologiczne. Znaleziska są stosunkowo młode i pochodzą głównie z XIX i XX w. Znane są przykłady zaklęć pisanych zarówno w języku niemieckim, jak i angielskim ${ }^{20}$.

Kontynuując omawianie środków przeciw szkodliwym działaniom, nie sposób pominąć innego fenomenu pochodzącego z Wysp Brytyjskich,

17 Ibidem, s. 69.

18 J.-M. Blaising, Archéologie des pratiques apotropä̈ques entre Lorraine et Luxembourg, w: Religion, cults \& rituals..., s. 347-356, tu: s. 351.

19 R. Merrifield, op. cit., s. 147-158.

20 P. J. Donmoyer, The concealment of written blessings in Pennsylvania barns, w: Manifestation of magic..., s. 179-196. 
który - jak się uważa - ma głównie regionalny zasięg. Niewykluczone jednak, że samo zjawisko nie zostało jeszcze poprawnie zidentyfikowane w innych częściach Europy. Chodzi w tym przypadku o depozyty naczyń, zwane powszechnie „butlami czarownic”, których do tej pory odnaleziono blisko 200. Co ciekawe, w większości przypadków konsekwentnie w roli podobnego rodzaju pojemników wybierano nadreńskie naczynia kamionkowe, zawierające na szyjce aplikację nakładkową z przedstawieniem brodatego mężczyzny. W środku opieczętowanych naczyń odnajduje się zazwyczaj gwoździe lub szpilki, fragmenty tkanin (wycinane nieraz na kształt serca), paznokcie, a nawet urynę ${ }^{21}$. Większość z nich datuje się na XVII i XVIII w. Ich kontekst odkrycia jest różny. Nieliczne zostały wykryte na brzegu Tamizy, inne były zakopane pierwotnie na otwartej przestrzeni. Jeden taki dzban został odnaleziony w Stepney (części Londynu) na działce, na której stał niewielki dom i znajdował się pierwotnie ogród. W naczyniu były ludzkie włosy i paznokcie, serce wycięte z tkaniny, kawałek drutu oraz zgięte szpilki. Naczynia podobnego rodzaju rejestrowano licznie w Suffolk na wschodzie Anglii. Jak się przypuszcza, to z tego regionu zwyczaj miał się rozpowszechnić na resztę kraju. Na zachodzie Anglii odnotowano ich mniej, lecz prawie wszystkie zostały zakopane w budynkach - pod progiem lub piecem, czyli w miejscach, które powszechnie łączy się z magią ochronną. Najpewniej uryna była bardzo ważnym składnikiem tego rodzaju depozytów. Butle wypełniano ludzkim moczem i zakopywano z intencją pozbycia się choroby. Dzięki informacjom z epoki wiadomo, że na podobnej zasadzie wykorzystywana była uryna pochodzenia zwierzęcego. Według zaleceń można było w ten sposób uleczyć np. niedomagającego konia. Powszechne było przeświadczenie, że za wieloma tymi problemami stoją czarownice sprowadzające choroby i nieszczęścia. Towarzystwo żelaznych, ostrych przedmiotów miało także sprawić im fizyczny ból. Aby wzmocnić działanie magii ochronnej, zalecano także, aby przed zakopaniem, ale po zakorkowaniu butli, podgrzać ją na ogniu. W XVIII w., kiedy ustała produkcja naczyń z wizerunkiem brodatego mężczyzny, w roli pojemników używano naczyń szklanych. W 2004 r. w Greenwich na głębokości 1,5 m odnaleziono oryginalnie zapieczętowane naczynie z wizerunkiem brodacza. Zostało ono prze-

21 R. Merrifield, op. cit., s. 163. 
kazane do analiz laboratoryjnych. W pierwszej kolejności wykonano zdjęcie rentgenowskie, które wykazało liczne przedmioty żelazne znajdujące się wewnątrz. Ponadto tomografia komputerowa wykonana na Uniwersytecie w Liverpoolu dowiodła, że pojemnik był do połowy wypełniony cieczą. Ciecz - po wydobyciu - została poddana analizie chemicznej, dzięki której udowodniono, że płyn był ludzką uryną. Dodatkowo obecność nikotyny w analizowanej próbce pozwoliła stwierdzić, że mocz należał do palacza. Wydobyto także resztę zawartości, wśród której znaleziono 12 żelaznych gwoździ, osiem szpilek z brązu, włosy, fragment skóry przebitej gwoździem oraz 10 obciętych paznokci ${ }^{22}$. Innego rodzaju naczynie, które także postrzega się jako dowód stosowania określonych zabiegów magicznych, pochodzi z Holyhead w Walii. Odnaleziony w 1871 r. garnek został przykryty fragmentem ceramiki, na której ktoś wydrapał imię i nazwisko - Nanny Roberts (ryc. 2). Uważa się, że garnek ten należał do osoby, wobec której zastosowano zaklęcie. W środku znajdowała się ciekawa zawartość. Były to kości oraz wysuszona skóra żaby przebita ok. 40 szpilkami. Podobnego rodzaju zabiegi mające szkodzić określonym osobom są znane z przekazów historycznych z Walii i miały być stosowane jeszcze w XIX w. ${ }^{23}$

Podejrzewa się, że zwyczaj ten również został przeniesiony przez angielskich osadników do Nowego Świata. Za butlę czarownic uznaje się znalezisko, jakie odkryto w 1976 r. w Essington w Pensylwanii w USA. Butelka, datowana na lata 1740-1750, została zakopana dnem do góry. Była zamknięta i zawierała sześć niezgiętych szpilek wykonanych z brązu. Zakopano ją w niewielkim, ale głębokim dole w pobliżu budynku pochodzącego z XVII w. ${ }^{24} \mathrm{Na}$ terenie Stanów Zjednoczonych do tej pory odnaleziono siedem podobnych naczyń ${ }^{25}$.

22 M. Pitts, Urine to navel fluff: the first complete witch bottle, „British Archaeology” 2009, vol. 107 (July/August), s. 7.

23 E. Gruffydd, A buckley pot used in witchcraft, „Buckley Society Magazine” 1981, vol. 6, s. 42; B. Hoggard, The archaeology of Folk Magic, „White Dragon”, Beltaine 1999, s. $17-20$.

${ }^{24}$ R. Merrifield, op. cit., s. 171-175.

25 M. C. Manning, The material culture of ritual concealments in the United States, w: Manifestation of magic..., s. 52-83. 


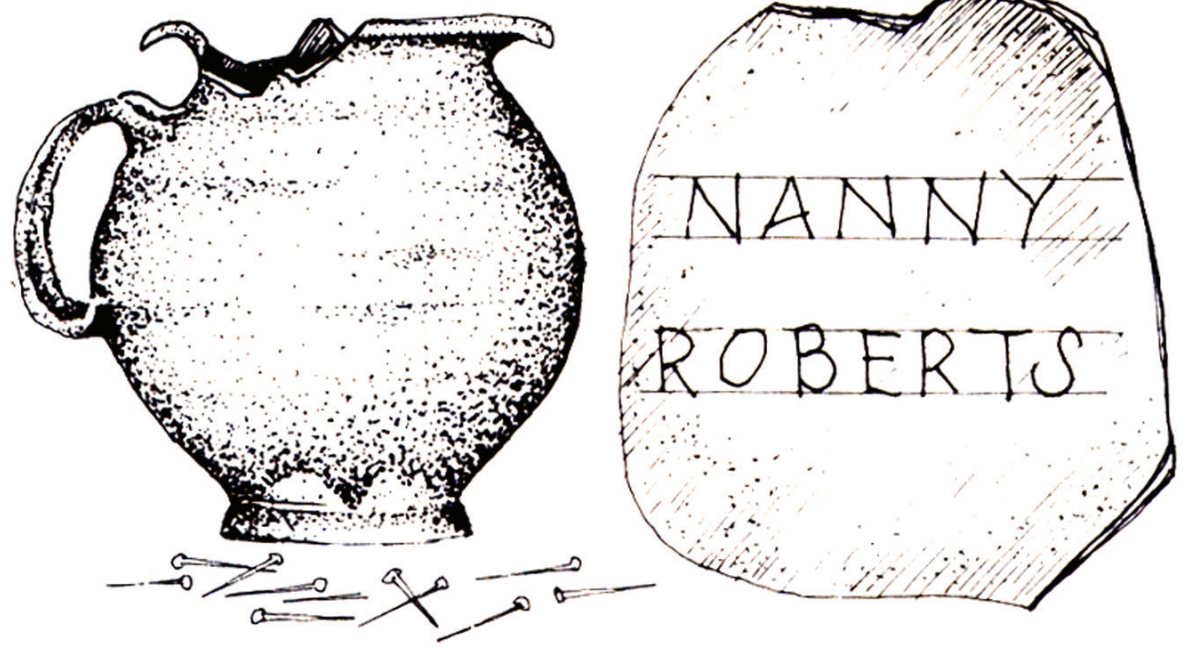

Ryc. 2. Rysunek naczynia razem z zawartością odnalezionego w Holyhead w Walii (Wielka Brytania). Źródło: E. Gruffydd, A buckley pot used in witchcraft, „Buckley Society Magazine" 1981, vol. 6

Oprócz opisywanych butli czarownic jest jeszcze odrębna grupa znalezisk zasługująca na uwagę. Zabytki te są szeroko rozpowszechnione, ale zostały odkryte i najlepiej rozpoznane na terenie Niemiec. Chodzi o łożyska poporodowe, deponowane w garnkach i umieszczane w miejscach niewidocznych - najczęściej w piwnicach lub pod podłogami budynków gospodarczych. Wierzono, że uchroni to łożyska przed ich wykorzystaniem podczas praktyk magicznych - głównie przez czarownice. Strach ten powodował również, że na niektórych z naczyń spotyka się dodatkowo malowane znaki apotropaiczne, jak pentagramy (ryc. 3), pojawiają się też inicjały (jak się przypuszcza - matek) oraz daty. Oprócz tego, że naczynie i sposób ukrycia chronił łożysko przed niepożądanymi osobami, to według relacji etnograficznych miał również zapewnić dziecku szczęście i powodzenie w życiu.

Zwyczaj ten po raz pierwszy został opisany przez Kurta Sartoriusa ${ }^{26}$ i jest obecnie potwierdzony w wielu częściach Europy. Znane są podobnego

26 U. Beitler, K. Sartorius, Mausefalle, Bauopfer oder Nachgeburtstopf? Zur Forschungsgeschichte eines vergessenen Brauches, w: "Wo weder Sonne noch Mond hinscheint". 

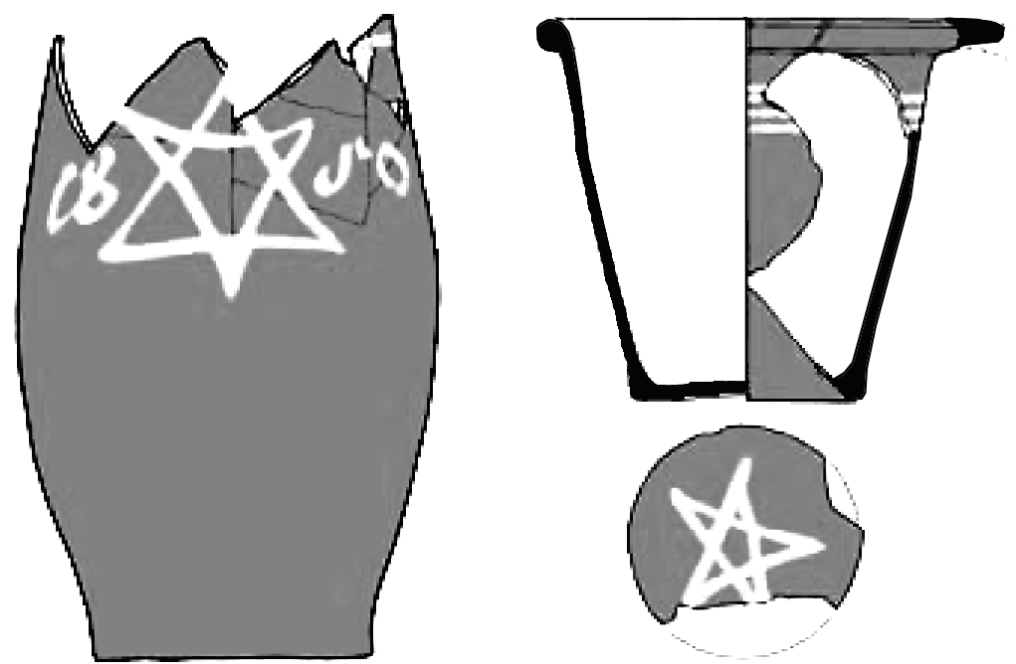

Ryc. 3. Heksagramy namalowane na naczyniach odnalezionych w Bönnigheim i Kirchheim unter Teck (Badenia-Wirtembergia, Niemcy). Przypuszczalnie złożono w nich łożyska poporodowe. Źródło: D. Ade, B. Schmid, Wo weder Sonne noch Mond hinscheint. Der Brauch der Nachgeburtsbestattung, w: Religiosität in Mittelalter und Neuzeit, Hrsg. M. Untermann, U. Matthias, Padeborn 2011, s. 233

rodzaju znaleziska z Łużyc ${ }^{27}$, Frankonii ${ }^{28}$ czy Polski. W przypadku Polski chodzi o liczne naczynia odnalezione w piwnicach budynków w Lubaniu. Odkryć tych dokonano w 20 lokalizacjach, w których ukryto ok. 100 naczyń. Niektóre z nich były przykryte pokrywkami lub kamieniami. Według datowania ceramiki zjawisko to utrzymywało się przynajmniej od XV/XVI do XIX w. Początkowo znaleziska były interpretowane jako ofiary zakładzinowe. Obecnie jednak znalazcy podejrzewają, że mogło chodzić o zwyczaj pochówków łożysk poporodowych. Naczynia trafiły na wystawę stałą prezentowaną

Archäologische Nachweise von Nachgeburtsbestattungen in der frühen Neuzeit, Hrsg. D. Ade-Rademacher et al., Stuttgart 1997, s. 11-16.

${ }_{27}$ M. Brumlich, Sexualhormon im Henkeltopf. Nachgeburtsbestattungen in Dörfern der Niederlausitz, „Archäologie in Berlin und Brandenburg” 2009, s. 137-139; idem, Gut vergraben am Gut. Eine neue Nachgeburtsbestattung aus Geisendorf, Lkr. Oberspreewald-Lausitz, „Archäologie in Berlin und Brandenburg” 2010, s. 159-161.

${ }^{28}$ E. D., H. Rosmanitz, Tatort Burg - Die Ausgrabungen auf der Burg Wildenstein, „Beiträge zur Archäologie in Ober- und Unterfranken” 2015, Bd. 9, s. 317-352. 
w Muzeum Regionalnym w Lubaniu. Niestety wyniki prac do tej pory nie zostały opublikowane ${ }^{29}$. Nie prowadzono także analizy chemicznej składu zawartości naczyń, a tylko ona może wskazać jednoznacznie na obecność tkanki ludzkiej w wypełnisku pojemnika w przeszłości i podtrzymać zaproponowaną interpretację. Jak wykazano, w praktyce trudno bez podobnych analiz odróżnić pochówki łożysk od np. pułapek na gryzonie. Były one również zakopywane w ziemi w podobny sposób w przeszłości ${ }^{30}$. Analiza sześciu naczyń, odkrytych w piwnicy budynku szkieletowego w Bodelshausen w Badenii-Wirtembergii, jednoznacznie wykazała, że pierwotnie w ich wnętrzu złożone były łożyska. Jedno naczynie po wydobyciu zostało zamrożone z zawartością i przecięte na pół. $Z$ profilu jego wypełniska pobrano próbki i poddano analizie biochemicznej. Analiza ta wykazała niezwykle wysoką koncentrację estradiolu w przydennej partii naczynia - hormonu żeńskiego (naturalnego estrogenu), którego stężenie w organizmie wzrasta w czasie ciąży i utrzymuje się do porodu ${ }^{31}$. Hormon ten jest produkowany w organizmie kobiecym również w łożysku. Analizie poddano także próbki glebowe pochodzące z otoczenia naczyń. Wyniki jednoznacznie wykluczyły zakłócenia wynikające z sąsiedztwa. Potwierdziły jednocześnie, że w przypadku odnalezionych naczyń z całą pewnością można wykazać praktykowanie zakopywania łożysk umieszczanych w naczyniach w piwnicy badanego budynku.

Podobne naczynia pojawiają się również w innych kontekstach niż tylko tych opisanych powyżej. Przykładem niech będzie miejscowość Zeicha w Saksonii, gdzie w trakcie badań odkryto grupę naczyń nowożytnych, zakopanych wzdłuż biegu strumienia ${ }^{32}$. Niewątpliwie jednak ten ciekawy

29 Zob. https://muzeumluban.pl/Pochowki_poplodowe (dostęp: 25.06.2018).

30 H. J. Szédeli, Nachgeburtstöpfe oder Tierfallen?, w: Archäologie auf der Überholspur. Ausgrabungen an der A 38, „Archäologie in Sachsen-Anhalt”, Bd. 5, Hrsg. H. Meller, Sonderband 2006, s. 255-259.

31 D. Ade, B. Schmid, Wo weder Sonne noch Mond hinscheint. Der Brauch der Nachgeburtsbestattung, w: Religiosität in Mittelalter und Neuzeit, Hrsg. M. Untermann, U. Matthias, Padeborn 2011, s. 227-236.

32 C. Matthes, Magische Rituale als Volksmedizin: Der Glaube neben dem Glauben. $Z u$ den frühneuzeitlichen Gefäßdeponierungen in Zeicha, Sachsen, w: ibidem, s. 237-250; idem, Begraben am Bach bei Zeicha: Eine frühneuzeitliche Gefäßdeponierung in Sachsen als 
problem jest nadal słabo poznany w Polsce, co może się również wiązać z jego niskim uświadomieniem wśród badaczy.

Zaprezentowany przegląd, skupiający się w głównej mierze na znaleziskach archeologicznych, jest jedynie zwróceniem uwagi na wiele problemów badawczych i interpretacyjnych. Zwyczaje dotyczące ukrywania podobnego rodzaju przedmiotów były bogate i trudne do jednoznacznego wytłumaczenia. Częstokroć osoba ukrywająca wiązała z faktem ukrycia rozbudowane i łączące się wzajemnie intencje. Zaliczały się do nich: chęć poprawy własnego losu i swojego inwentarza, działania ochronne przed czarownicami, ale też pragnienie zapewnienia ogólnego szczęścia domownikom przez modlitwy i znaki oraz zaklęcia, które stały w sprzeczności z oficjalnymi naukami Kościoła. Celowo pominęliśmy przegląd znalezisk wątpliwych - takich, gdzie interpretacja została oparta na słabych podstawach lub trudnych obecnie do ponownej weryfikacji. Należy również zaznaczyć, że wiele z prezentowanych, nawet pobieżnie, wyników badań nie było znanych polskiemu czytelnikowi. Znaleziska ukazują różnice regionalne w ich stosowaniu, lecz również uniwersalność pewnych symboli i rozwiązań, obecną na szerokim terenie i pojawiającą się w znacznych odległościach od siebie. Niewątpliwie odkrycia te należą do jednych z najbardziej sensacyjnych, jakie wystąpiły w materiale archeologicznym. Wydaje się, że jedynie włączanie do obiegu podobnego rodzaju znalezisk i ich rzetelna ocena przyczyni się do zmiany lub obalenia schematów interpretacyjnych, które pojawiły się w innych warunkach i okolicznościach - często określonych brakiem odpowiednich metod, a więc współcześnie anachronicznych. Może uda się także ponownie zanalizować archiwalne, niepublikowane, znaleziska i włączyć je do którejś z grup prezentowanych wyżej.

Indikator volksmedizinischer Rituale, w: Glaube - Aberglaube - Tod. Vom Umgang mit dem Tod von der Frühgeschichte bis zur Neuzeit, Hrsg. I. Beilke-Voigt, F. Biermann, „Ethnographisch-Archäologische Zeitschrift” 2009, Bd. 50 (1-2), s. 163-177. 
